DOI: $10.26693 / j m b s 06.06 .074$

UDC 611.83/.92:611.984

Oliinyk I. Yu., Tsyhykalo O. V., Koval O. A.

\title{
FEATURES OF BLOOD SUPPLY TO THE BONES OF THE LOWER LEG IN THE ANKLE JOINT REGION
}

\author{
Bukovinian State Medical University, Chernivtsi, Ukraine
}

The purpose of the study was to investigate the topography of permeable (nutrition) arteries in the lower third of leg during human ontogenesis.

Materials and methods. The research was conducted on 30 specimens of human prefetuses and fetuses aged 3-9 months of prenatal development; 28 bone specimens of adult tibia and fibula and 27 series of computerized tomography scans of lower extremities of adults aged 21-72 were used. We have used a complex of methods for morphological research: anthropometry, morphometry, macromicroscopy, injections of blood vessels of X-ray contrasting mixtures, three-dimensional reconstruction and statistical analysis.

Results and discussion. Cartilage osteogenesis occurs in the prefetal period of prenatal human development, in which blood vessels play a crucial morphofunctional role. During endochondral ossification of the tibia, the vessels of the bone cuff grow into the diaphysis of the cartilaginous model of the bone and osteogenic cells go beyond their limits.

In the third trimester of prenatal development, blood vessels grow into the epiphyseal part of the cartilaginous model and an epiphyseal centre of ossification forms. Between the epiphysis and diaphysis centers of ossification, a metaphysical growth plate forms that develops intraosseous anastomosis between the diaphyseal and metaphysical blood vessels. In the metaphysis region, there are extra-skeletal anastomoses.

Often, the insertion of nutrition arteries into the bone of the tibia is usually the middle third of bones (55\%) and distal metaphysis (37\%). In 10\%, there were nutrition foramina in the upper third of the tibia.

Three-dimensional reconstruction also clearly shows a more extensive and developed network of vessels in the bone marrow canal in metaphysical regions. In the middle third of the tibia and fibula, 1-3 nutrient foramina can be traced on most specimens.

On the fibular, in addition to the posterior-medial localization of the nutrient arteries, there were variants with a "high" (above the metaphysis) placement of the entrance of the vessel into the bone substance.

Conclusion. The most common places where arteries enter the bones of the lower leg are the middle third of the bones (55\%) and the distal metaphysis $(37 \%)$. In $10 \%$, there were nutrient foramina in the upper third of the tibia. The three-dimensional recon- struction also clearly shows a more extensive and developed network of vessels in the bone marrow canal in metaphysical regions. During the postnatal period, we most often encountered the localization of nutritional arteries on the anterior-lateral surface of the tibia $(23 \%)$, or their combination - the presence of both nutrient arteries on the posterior and medial bone surfaces (18.3\%).

Keywords: bones of the lower leg, blood supply, ankle joint, ontogenesis, human.

Relationship of work with scientific programs, plans, and topics. The study is a fragment of the research work of the Department of Histology, Cytology and Embryology of Bukovinian State Medical University «Structural and functional features of tissues and organs in ontogenesis, patterns of variant, constitutional, gender, age and comparative human morphology», state registration number $0121 \mathrm{U} 110121$.

Introduction. Morphological studies of the features of blood supply to human limbs, clarification of the variant anatomy of the nutrient arteries is a topical issue which anatomists and orthopaedic traumatologists face nowadays [1-4]. The need to preserve arterial vessels during surgical fixation of fractures and ensuring adequate blood supply to the limb can be determining factors in choosing the method of osteosynthesis. Types of fractures of the lower third of the lower leg and the ankle joint region involve certain surgical tactics - whether it is the use of plates or wires.

Analysis of scientific sources has shown that research work on the blood supply to the ankle joint, with rare exceptions, is almost non-existent. This fact is obviously explained by the fact that this issue is more or less described in detail in the literature of past centuries and today is probably considered exhausted. Even the great anatomical guide to angiology mentions the arterial supply of the ankle joint in passing. Moreover, this applies to the description of the blood supply to the joint in both adults $[5,6]$ and newborns [7]. However, the blood supply to the ankle joint has its own characteristics, which depend on many reasons and require consideration in certain situations [8]. First of all, these features are influenced by the genotype-controlled anatomical variability of the structure of the main arterial vessels of the tibia, 
which are involved in the trophism of the ankle joint [9].

Clarification of the topography of permeable arteries in this part of the lower limb will allow us to choose a known optimal method or develop a new one for immobilizing fractures, avoid postoperative complications, and increase the effectiveness of treatment [10-12].

The purpose of the study was to find out the topography of permeable arteries in the lower third of the lower leg during human ontogenesis.

Materials and methods. We studied specimens of 30 human pre-fetuses and fetuses aged 3-9 months of intrauterine development from the collection of the Department of Histology, Cytology and Embryology, 28 bone specimens of the lower extremities of people of different ages and genders from the Museum of the Department of Human Anatomy named after M. H. Turkevich of Bukovinian State Medical University, as well as three-dimensional reconstructions based on 27 series of CT (computerized tomography) scans of adults aged 21-72 years. Blood vessels from specimens of human fetuses were contrasted with a mixture based on minimum. The following morphological research methods were used: anthropometry - to determine the age of human fetuses, morphometry to obtain digital indicators, macromicroscopy and three-dimensional reconstruction - to determine the features of development and topography of the permeable arteries of the lower limb.

The study was conducted in compliance with the main bioethical provisions of the Council of Europe Convention on Human Rights and Biomedicine (dated 04.04.1997), World Medical Association Declaration of Helsinki: ethical principles for medical research involving human subjects (1964-2008), orders of the Ministry of Health of Ukraine No. 690 dated 23.09.2009, No. 616 dated 03.08.2012 and according to methodological recommendations [13] and «The procedure for removing biological objects from the deceased, whose bodies are subject to forensic medical examination and pathoanatomical research, for scientific purposes» [14].

Research results. During the prenatal period of human prenatal development, cartilaginous osteogenesis occurs, in which blood vessels play a crucial morpho-functional role. At the stage of endochondral ossification of the bones of the lower leg, the vessels of the bone cuff grow into the diaphysis of the cartilage model of the bone and osteogenic cells go beyond them. Due to the activity of osteoclasts, resorption cavities appear in the cartilage, which, merging, form a medullary cavity (Fig. 1). At the last stage of bone formation (the third trimester of prenatal development), blood vessels grow into the epiphyseal part of the cartilage model, and the epiphyseal ossification centre forms. Between the epiphyseal and diaphyseal centres of ossification, a metaphyseal growth plate forms, which has a complex morphological structure and develops intra osseous anastomoses between diaphyseal and metaphyseal blood vessels. A characteristic feature of the topography of blood vessels in the metaphysis is extraosseous anastomoses - arterial branches that are supra- and submetaphyseal branches of nutrient blood vessels. They are the descending branches of the main arteries of the lower leg.

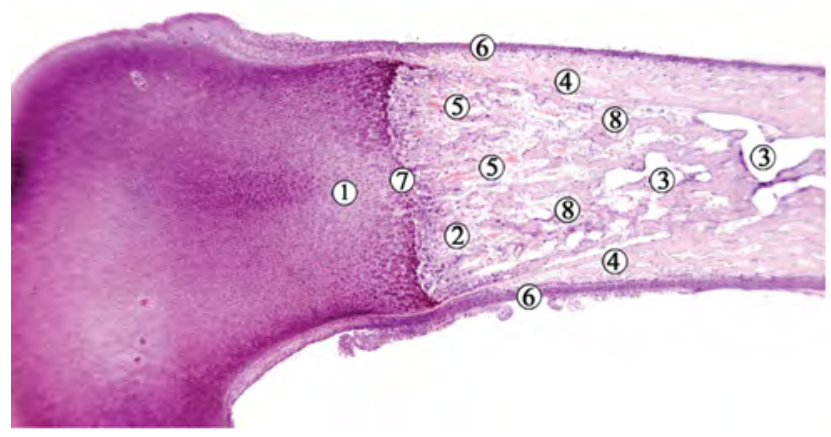

Fig. 1 - Longitudinal section of the tibia of a 3.5-monthold human fetus. Hematoxylin and eosin staining. Microphotograph. Zoom $\times 40$ :

1 - unchanged epiphyseal cartilage zone; 2 - calcified cartilage zone; 3 - medullary cavity; 4 - perichondrium; 5 - blood lacunae; 6 - a germ of the periosteum; 7 metaepiphyseal growth plate; 8 -islands of endochondral ossification

According to the results of our research, the most common places where arteries enter the bones of the lower leg are the middle third of the bones (55\%) and the distal metaphysis (37\%) (Fig. 2). 10\% had nutrient foramina in the upper third of the tibia.

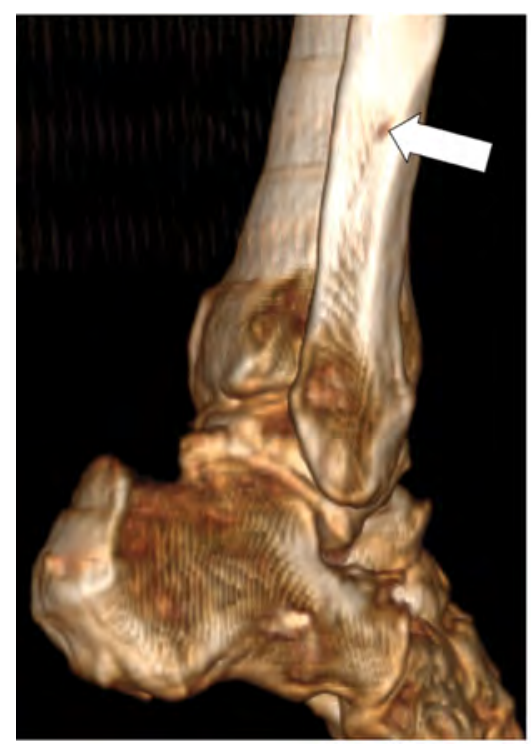

Fig. 2 - Three-dimensional reconstruction of a 46-yearold man's right lower limb. Posteromedial projection. The arrow indicates nutrient foramen 
Three-dimensional reconstructions also clearly show a more extensive and developed network of vessels in the bone marrow canal in metaphyseal regions (Fig. 3). In the middle third of the tibia and fibula, 1-3 nutrient foramina can be traced on most specimens (Fig. 4).

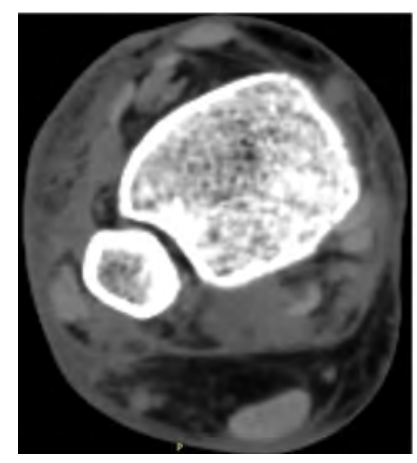

Fig. 3 - CT scan of a 46-year-old man's right lower limb. Cross-section

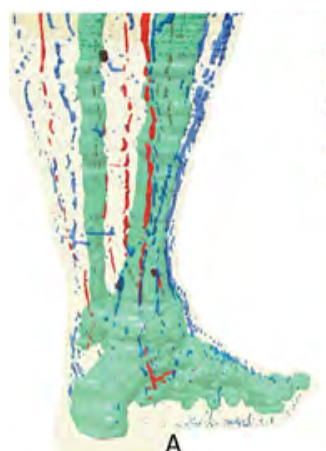

A

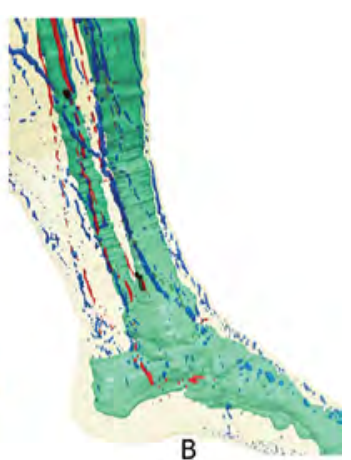

B
Fig. 4 - Three-dimensional computer reconstruction of a 70-year-old man's left lower limb. A - posterior projection; $B$ - medial projection.

Black marks show the entry points of nutrient vessels

In the postnatal period, most often we identified localization of nutrient arteries on the anterolateral surface of the tibia $(23 \%)$, or a combination of them the presence of simultaneously nutrient bone arteries on the posteromedial and posterolateral surfaces of the bone (18.3\%) (Fig. 5).

On the fibula, in addition to the posterior-medial localization of the nutrient arteries, there were variants with a «high» (above the metaphysis) place of entry of the vessel into the bone substance. Sources of blood supply to the lower third of the tibia are the anterior tibial artery, and the fibula - the fibular (peroneal) artery. The use of computer reconstruction methods enables obtaining three-dimensional models of limb tissues in order to model the method of fixing pilon fractures further, which makes it possible to individualize the method of their treatment. It is established that the places of entry of nutrient arteries into the compact substance of the tibia and fibula are variant and require further study and systematization of individual and typological variability.

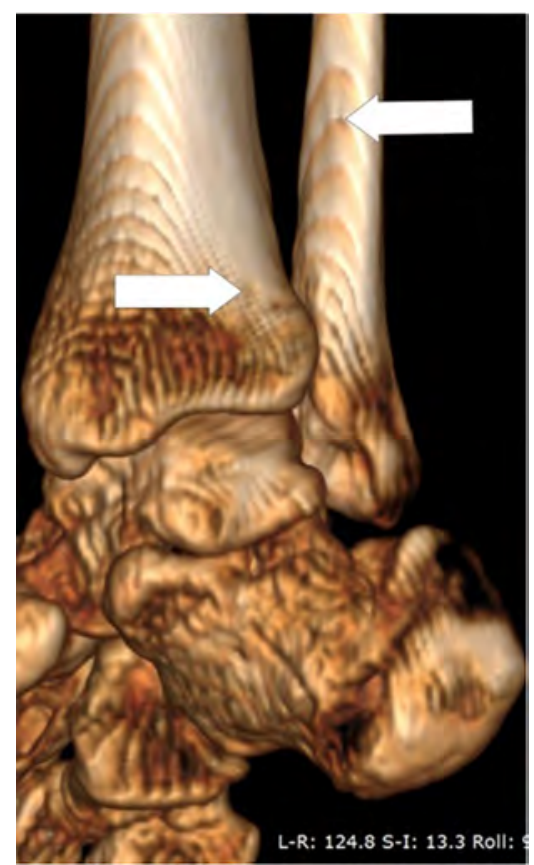

Fig. 5 - Three-dimensional reconstruction of a middleaged man's right lower limb. Posterior-lateral projection. Arrows indicate nutrient foramina

Discussion. The blood supply to the ankle joint region is carried out by the branches of the three main arteries of the tibia (fibular, anterior and posterior tibial arteries), which in the area of the ankle form two arterial networks - lateral and medial [15]. Branches from some arteries of foot also take part in formation of these grids. Anatomical variants of the tibial arteries are due to the predominance in the development of one of the arteries of the leg - from various degrees of underdevelopment (partial reduction) to the complete absence (complete reduction) of a vessel. At the same time, underdevelopment of one artery to compensate for the blood supply to the ankle joint and the foot as a whole, is accompanied by increased development of the other artery. According to the literature, underdevelopment of the anterior tibial artery is observed in the range from $0.5 \%$ to $10.9 \%$ of cases, the absence of this artery is rare [16-18]. Weak development of the posterior tibial artery is observed somewhat less frequently than the anterior - in $0.6-6 \%$ of cases, but this artery is absent in $0.8-5.2 \%$ of cases [19]. In this situation, one of the absent or partially reduced arteries, and sometimes both tibial arteries are replaced by a highly developed fibular artery.

Reduction of the fibular artery is uncommon in $0.7-3 \%$ of cases, and its absence - an extremely rare phenomenon. It is no coincidence that the fibular artery is considered by many researchers [20-22] to be the main and most stable arterial vessel of the leg.

In our study, we also found high variability in the anatomical structure of the arteries of the leg, which undoubtedly affects the variability of the blood supply to the ankle joint. It should also be born in mind that 
the studies of the above authors were usually conducted in sampleless populations, i.e. without taking into account the genotypic characteristics of the material. Kiselevsky Yu.M. [23] confirmed this position by conducting a complex of anatomical methods (macromicroscopic preparation, injection of arteries with Xray angiography) study on genetically heterogeneous material. Based on the data obtained as a result of the study, it was stated that the most stable source in the blood supply of the ankle joint is the fibular artery, which compensates for the loss of blood flow in cases of underdevelopment of the tibial arteries.

Conclusion. The most common places where arteries enter the bones of the lower leg are the middle third of the bones $(55 \%)$ and the distal metaphysis (37\%) (Fig. 2). 10\% had nutrient foramina in the upper third of the tibia. Three-dimensional reconstructions also clearly show a more extensive and devel- oped network of vessels in the bone marrow canal in metaphyseal regions. In the postnatal period, most often we identified localization of nutrient arteries on the anterolateral surface of the tibia $(23 \%)$, or a combination of them - the presence of simultaneously nutrient bone arteries on the posteromedial and posterolateral surfaces of the bone (18.3\%).

Perspectives of further research. We consider it appropriate to proceed with the study of the features of blood supply to the bones of the lower limb with the determination of gender, age and constitutional features of blood vessels and localization of nutrient foramina. Patterns of the variant vascular anatomy of the lower extremities can serve as a morphological basis to substantiate and develop new methods for the treatment and prevention of complications of fractures of the lower leg and ankle joint.

\section{References}

1. Anusha P, Naidu MP. A study on the nutrient foramina of long bones. Jour of Med Sc and Tech. 2013;2(3):150-7.

2. Bilodi AKS, Reddy BS. A study on nutrient foramina of fibula, its medicolegal aspect and clinical importance in dentistry. World J Pharmacy Pharmaceutic Sci. 2018;3(2):2133-44.

3. Gupta R, Singh KA, Rajkumar. Morphological Study of Nutrient Foramen in Human Fibulae of North Indian Region. Int J Med Health Sci. 2013;2(2):205-9.

4. Sanjeev K, Kathiresan K, Trinesh G, Nagalaxmi. Study of Diaphysial nutrient Foramina in human long bones. Anat Kar. 2017;6(2):66-70. doi: 10.1016/j.jasi.2017.08.239

5. Kiselevskiy YuM. Obzor variantov stroeniya arterialnoy sistemyi goleni [Overview of options for the structure of the arterial system of the leg]. Minsk; 1998. 11 s. [Russian]

6. Kovanov VV, Anikina TI. Hirurgicheskaya anatomiya arteriy cheloveka [Surgical anatomy of human arteries]. M: Meditsina, 1974. 360 s. [Russian]

7. Topografo-anatomicheskie osobennosti novorozhdennogo [Topographic and anatomical features of the newborn]. Pod red EM Margorina. L: Meditsina; 1977. 280 s. [Russian]

8. Kisielewski J. Warianty budowy tetnic goleni noworodkow (aspekt kliniczny) [Variants of the structure of shin arteries of newborns (clinical aspect)]. Streszcz ref IV Swiat Kong Pol Med. Warszawa; 2000. s. 84-85. [Poland]

9. Kisielewski J. Wiaftciwoaci zaopatrzenia w krew stawyw kozyny dolnej noworodkyw z zespoiami chromosomalnymi (trisomia 13, 18, 21) [Invalid blood supply to the lower leg joints of newborns with chromosomal syndromes (trisomy 13, 18, 21)]. Streszcz XXVII Ogylnopol Zjazdu Pediatiyw. Bydgoszcz; 2003. 2003. s. 162. [Poland]

10. Kanczler JM, Oreffo RO. Osteogenesis and angiogenesis: the potential for engineering bone. Eur Cell Mater. 2008;15(2):100-14. PMID: 18454418. doi: 10.22203/eCM.v015a08

11. Patel SM, Vora RK, Jotania BM. A Study Of Diaphyseal Nutrient Foramina In Human Lower Limb Long Bones. NJIRM. 2015;6(3):14-8.

12. Sharma MD, Mathur A, Nagar AK, Barjatiya R, Chauhan $P$, Shekhawat S. Study of Morphometric Variations in the Nutrient Foramina of Fibula in Central Rajasthan. Indian J Clin Anat Physiol. 2016;(1):65-71. doi: 10.5958/23942126.2016.00017.7

13. Mishalov VD, Chaikovskyi YuB, Tverdokhlib IV. Dotrymannia etychnykh i zakonodavchykh norm $i$ vymoh pry vykonanni naukovykh morfolohichnykh doslidzhen [Adherence to ethical and legal norms and requirements in the performance of scientific morphological research]. K; 2007. 76 s. [Ukrainian]

14. Mishalov VD, Voichenko VV, Malysheva TA, Dibrova VA, Kuzyk PV, Yurchenko VT. Poriadok vyluchennia biolohichnykhobiektivvid pomerlykh, tilayakykh pidliahaiutsudovo-medychniiekspertyziipatolohoanatomichnomu doslidzhenniu, dlia naukovykh tsilei: metodychni rekomendatsii [The procedure for removing biological objects from the dead, whose bodies are subject to forensic examination and pathological examination, for scientific purposes: guidelines]. Osvita Ukrainy: spetsvypusk. Kyiv: Pedahohichna presa. 2018;2(62):3-13. [Ukrainian]

15. Andriesh VN, Negina SG, Yastrebova TA, Lupashku FI. Krovosnabzhenie i innervatsiya sustavov cheloveka [Blood supply and innervation of human joints]. Kishinev; 2001. 344 s. [Russian] 
16. Warchoł Ł, Mróz I, Mizia E, Zawiliński J, Depukat P, Kurzydło W, et al. Vascular density of inferior tibiofi bular joint: cadaveric experimental study. Folia Med Cracov. 2017;57(1):47-54.

17. Gosselin MM, Haynes JA, McCormick JJ, Johnson JE, Klein SE. The arterial anatomy of the lateral ligament complex of the ankle: a cadaveric study. Am J Sport Med. 2019;47(1):138-43. PMID: 30452871. doi: 10.1177/0363546518808060

18. Giebel GD, Meyer C, Koebke J, Giebel G. The arterial supply of the ankle joint and its importance for the operative fracture treatment. Surg Radiolog Anatom. 1997;19(4):231-5. PMID: 9381328. doi: 10.1007/BF01627863

19. Vazquez T, Rodríguez-Niedenfuhr M, Parkin I, Viejo F, Sanudo J. Anatomic study of blood supply of the dorsum of the foot and ankle. Arthroscopy: J Arthroscop Related Surg. 2006;22(3):287-90. PMID: 16517313. doi: 10.1016/j.arthro.2005.10.021

20. Tennant JN, Rungprai C, Pizzimenti MA, Goetz J, Phisitkul P, Femino J, et al. Risks to the blood supply of the talus with four methods of total ankle arthroplasty: a cadaveric injection study. JBJS. 2014;96(5):395-402. PMID: 24599201. doi: 10.2106/JBJS.M.01008

21. Hootnick DR. Congenital fibular dystrophisms conform to embryonic arterial dysgenesis. Anatom Record. 2020;303(11):2792-800. PMID: 31872958. doi: 10.1002/ar.24348

22. Olewnik $Ł$, Łabętowicz P, Podgórski M, Polguj M, Ruzik K, Topol M. Variations in terminal branches of the popliteal artery: cadaveric study. Surg Radiolog Anatom. 2019;41(12):1473-82. PMID: 31134299 PMCID: PMC6853856. doi: 10.1007/s00276-019-02262-3

23. Kiselevskiy YuM. Krovosnabzhenie i innervatsiya golenostopnogo sustava u plodov i novorozhdennyih detey [Blood supply and innervation of the ankle joint in fetuses and newborns]. Zhurnal GGMU. 2005;3:121-3. [Russian]

\section{УДК 611.728.4:612.13 \\ ОСОБЕННОСТИ КРОВОСНАБЖЕНИЯ КОСТЕЙ ГОЛЕНИ \\ В ОБЛАСТИ ГОЛЕНОСТОПНОГО СУСТАВА \\ Олийнык И. Ю., Цигикало А. В., Коваль О. А.}

Резюме. Цель. Выяснить топографию питательных артерий в нижней трети голени в онтогенезе человека.

Материал и методы. Исследованы препараты 30 предплодов и плодов человека 3-9 месяцев внутриутробного развития, 28 большеберцовых и малоберцовых костей и 27 серий компьютерных томограмм нижних конечностей людей в возрасте 21-72 лет. Использован комплекс методов морфологического исследования: антропометрия, морфометрия, макро- и микроскопии, введения в кровеносные сосуды рентгеновских контрастных препаратов, трехмерная реконструкция и статистический анализ.

Результаты. В предплодном периоде пренатального развития человека происходит хрящевой остеогенез, в котором кровеносные сосуды играют решающую морфофуункциональную роль. На этапе энхондрального окостенения костей голени происходит прорастание сосудов костной манжетки внутрь диафиза хрящевой модели кости и выход за их пределы остеогенных клеток. В третьем триместре пренатального развития кровеносные сосуды врастают в эпифизарную часть хрящевой модели, образуется эпифризарный центр окостенения. Между эпифизарным и диафизарным центрами окостенения формируется метафизарная пластинка роста, которая имеет развитые внутрикостные анастомозы между диафизарными и метафизарными кровеносными сосудами. В области метафиза обнаруживаются внекостные анастомозы. Часто местами вхождения питательных артерий в кости голени является их средняя треть (55\%) и дистальный метафиз (37\%). У 10\% случаев обнаружено питательные отверстия в верхней трети большеберцовой кости. На трехмерных реконструкциях четко видно также более разветвленную и развитую сеть сосудов в костномозговом канале в метафизарных участках. В средней трети большеберцовых и малоберцовых костей на большинстве препаратов прослеживается 1-3 питательных отверстий. На малоберцовой кости, кроме заднемедиальной локализации питательных артерий, встречались варианты с «высоким» (выше метафиза) размещением места вхождения сосудов в вещество кости.

Выводы. На разных этапах онтогенеза человека чаще всего местами вхождения питательных артерий в кости голени является их средняя треть (55\%) и дистальный метафиз (37\%). У $10 \%$ обнаружено питательные отверстия в верхней трети большеберцовой кости. На трехмерных реконструкционных моделях четко определяется разветвленная и развитая сеть сосудов в костномозговом канале в метафизарных участках. В постнатальном периоде чаще всего питательные артерий локализуются на переднелатеральной поверхности большеберцовой кости (23\%), или же сочетание - наличие одновременно питательных костных артерий на заднемедиальной и заднелатеральных поверхностях кости (18,3\%).

Ключевые слова: кости голени, кровоснабжение, голеностопный сустав, онтогенез, человек. 


\section{УДК 611.83/.92:611.984}

\section{ОСОБЛИВОСТІ КРОВОПОСТАЧАННЯ КІСТОК ГОМІЛКИ \\ В ДІЛЯНЦІ НАДП'ЯТКОВО-ГОМІЛКОВОГО СУГЛОБА \\ Олійник І. Ю., Цигикало О. В., Коваль О. А.}

Резюме. Мета. З'ясувати топографію живильних артерій у нижній третині гомілки в онтогенезі людини.

Матеріал та методи. Досліджено препарати 30 передплодів та плодів людини 3-9 місяців внутрішньоутробного розвитку, 28 великогомілкових і малогомілкових кісток і 27 серій комп'ютерних томограм нижніх кінцівок людей віком 21-72 років. Використано комплекс методів морфологічного дослідження: антропометрія, морфометрія, макро- і мікроскопії, введення у кровоносні судини рентгенівських контрастних препаратів, тривимірне реконструювання та статистичний аналіз.

Результати. У передплодовому періоді пренатального розвитку людини відбувається хрящовий остеогенез, в якому кровоносні судини відіграють вирішальну морфо-функціональну роль. На етапі енхондрального скостеніння кісток гомілки відбувається проростання судин кісткової манжетки всередину діафіза хрящової моделі кістки і вихід за їх межі остеогенних клітин. У третьому триместрі пренатального розвитку кровоносні судини вростають в епіфрізарну частину хрящової моделі, утворюється епіфрізарний центр скостеніння. Між епіфізарним та діафізарним центрами скостеніння фрормується метафізарна пластинка росту, яка має розвинуті внутрішньокісткові анастомози між діафізарними та метафрізарними кровоносними судинами. В ділянці метафізу є позакісткові анастомози. Часто місцями входження живильних артерій у кістки гомілки є середня третина кісток (55\%) та дистальний метафіз (37\%). У 10\% випадків виявлено живильні отвори у верхній третині великогомілкової кістки. На тривимірних реконструкціях чітко визначається розгалужена та розвинута сітка судин у кістково-мозковому каналі в метафізарних ділянках. У середній третині великогомілкових і малогомілкових кісток на більшості препаратів простежується 1-3 живильних отвори. На малогомілковій кістці, крім задньоприсередньої локалізації живильних артерій, зустрічалися варіанти з «високим» (вище метафіза) розміщенням місця входження судини в речовину кістки.

Висновки. На різних етапах онтогенезу людини найчастіше місцями входження живильних артерій у кістки гомілки є їхня середня третина (55\%) та дистальний метафріз (37\%). У $10 \%$ виявлено живильні отвори у верхній третині великогомілкової кістки. На тривимірних реконструкційних моделях чітко визначається розгалужена та розвинута сітка судин у кістково-мозковому каналі в метафрізарних ділянках. У постнатальному періоді найчастіше живильні артерії зосереджені на передньобічній поверхні великогомілкової кістки (23\%), або ж поєднання - наявність одночасно живильних кісткових артерій на задньоприсередній та задньобічній поверхнях кістки (18,3\%).

Ключові слова: кістки гомілки, кровопостачання, надп'ятково-гомілкового суглоба, онтогенез, людина.

\section{ORCID and contributionship:}

Ihor Yu. Oliinyk : 0000-0002-6221-8078 A,C,E,F

Alexander V. Tsyhykalo : 0000-0003-2302-426X A,B,D

Alexander A. Koval: 0000-0002-9434-8213 A,C,E,F

A - Work concept and design, B - Data collection and analysis,

C - Responsibility for statistical analysis, D - Writing the article,

E - Critical review, F - Final approval of the article

\section{CORRESPONDING AUTHOR}

Ihor Yu. Oliinyk

Bukovinian State Medical University,

Pathological Anatomy Department

5a, Rivnens'ka Str., apt. 47, Chernivtsi 58013, Ukraine

tel: +380501943577, e-mail: olijnyk1961@gmail.com

The authors of this study confirm that the research and publication of the results were not associated with any conflicts regarding commercial or financial relations, relations with organizations and/or individuals who may have been related to the study, and interrelations of coauthors of the article. 